\title{
MYTH AND THE POETICS OF THE SELF:
}

\section{The Critical Corpus of Gémino H. Abad}

\author{
J. Neil C. Garcia \\ University of the Philippines-Diliman \\ jneilgarcia@gmail.com
}

\begin{abstract}
About the Author
J. Neil C. Garcia teaches creative writing and comparative literature in the University of the Philippines, Diliman, where he serves as Director of the university press and a fellow for poetry in the Institute of Creative Writing. He is the author of numerous poetry collections and works in literary and cultural criticism, including The Sorrows of Water (2000), Kaluluwa (2001), Performing the Self: Occasional Prose (2003), The Garden of Wordlessness (2005), Misterios and Other Poems (2005), and Postcolonialism and Filipino Poetics: Essays and Critiques (2003). In 2009, Hong Kong University Press published its own international edition of his Philippine Gay Culture (1996). Between 1994 and 2006, he coedited the famous Ladlad series of Philippine gay writing. His most recent books are The Postcolonial Perverse: Critiques of Contemporary Philippine Culture, and Homeless in Unhomeliness: Postcolonial Critiques of Philippine Literature, both published in 2014. He is currently at work on "Likha," his seventh poetry book.
\end{abstract}


Once upon a time (the late 1990s, actually), Jimmy and I wrote long and nerdy letters to each other-via email. He would go abroad for some teaching stint or other, and the conversation that we had routinely enjoyed inside his FC office would, soon enough, transform into an electronic correspondence, my side of which I have fortunately mostly saved for posterity: at the time, I wrote my letters out as Word documents first...

I'm bringing this up because, after listening to Jimmy's most recent lecture-a "creative-critical manifesto" that he delivered in this very samevenue a couple of weeks ago $^{2}$-I realize that the topic of one of our longer and more hearty conversations then has, for him, remained luminously germane, and that his position on the matter has remained entirely and admirably consistent. I'm referring to the vexed (and vexing) question of subjectivity, referenced eloquently in Jimmy's abiding faith in the poet's expressive and untrammeled imagination-which is to say, her freely determining humanist self.

As in that digital exchange, evident in this manifesto's declaration-that "every literary work shows our humanity," which is "the source of its power to move us," and that the writer's task is "to endow [a given language] with [dynamic] form"is the steadfast belief that (quoting from one of his emails) "poets have never lost that Self and continue to celebrate it... poetry would be impossible without that Self, that soul, that universal human nature." I must admit that in our protracted exchange I valiantly tried and tried-using a variety of historicist propositions- to argue against this essential and humanistic faith.

As far as this mission is concerned I'm happy to report (then, as now) that I spectacularly and miserably failed...

And this is how it went.

At first, contemplating the question of the "unified self," I gave Jimmy the standard postmodern spiel on the fragmentary historical subject, invoking the "legion" of selves that $I$ provisionally inhabit as a convenient if not slightly hyperbolic example: writer (I dare not say, "poet"), critic, educator, gay man, devout Catholic, feminist, effeminist, materialist, spiritualist, lover, friend, socialist, activist, global, local, among others... Of course, what I meant to accomplish with this list was to trouble the conceit of my earlier claim to a single and singular self-basically by specifying its varied cognitive and emotional occasions and affinities. Recognizing that contradictions must inhere in this endeavor, I then invoked the African philosopher Anthony Kwame Appiah's peace-making intervention in the war between the "humanist artist" and the "poststructuralist critic," stressing the familiar and obvious 
point that paradoxes of the subject-positional sort are pretty normal in our day and age.

Appiah's equable "solution" was, of course, to say that one's account of "freedom" doesn't need to cancel out the other's account of "determination,"3 simply because these accounts are different and don't even converse with one another, although precisely for this reason they conceivably bear their own unique usefulnesses.

What's interesting is that Appiah's interlocutory examples aren't necessarily two different persons as, indeed, in this case, the "soulful artist" and the "cultural critic" happen to be intimately acquainted with one another on a more-or-less regular basis for quite sometime now; that is to say, they are both and at once myself. To argue my shameless case even further, I then confided to Jimmy that a personal "idol" of mine in this regard is the great Theodor Adorno, a Marxist of the Frankfurt School, whose critical despair concerning the ascendancy of "instrumental rationality" in capitalist Europe was counterpointed by his unshakeable faith in the formal autonomy of modernist art, from which he managed to wrest a modicum of joyhe took up composition courses under the avant-garde musician, Alban Berg-and through which he was able to theorize, toward the end of his life, a powerful and more hopeful albeit eminently discombobulating aesthetics. ${ }^{4}$

Soon enough, however, I humbly acknowledged the fact that, despite or precisely because of these postfoundationalist demurrals, what we may provisionally call the "humanist self" hasn't disappeared or been discoursed out of existence at all. It has simply diversified and become "fractal" and intractable. Like scriptural loaves and fishes, modernity's unified self, characterized by presumptive sameness, has miraculously "multiplied," which is another way of saying it has divided, dashed as it has repeatedly been against the floor of history's wars and catastrophes, from which it has slowly and painfully dissolved back into the plenitude of sentient bodies and differences it has sought to silence and to subsume-indeed, to silence by subsuming_during the heyday of all our sad little world's imperialisms...

And so, yes, in the course of our often-strange correspondence, it gradually dawned on me that Freud's "unconscious," Nietzsche's "Ubermensch," the "alienated self" of modernism, Marxism's "social being," Foucault's "discursive subject," de Beauvoir's "second sex," Levinas's "alterity," Rich's "lesbian," Said's "New Arab," Bhabha's "hybrid," Spivak's "subaltern" and Gates's "signifying monkey" - these may be seen as ways of talking about embodied difference that anticipate and exemplify it at the same time that they name it. They're nothing if not our troubled world's most recent performances of subjectivity that seek to lay bare the speaking subject's illusiveness (and elusiveness) - that pry it apart if only to recover some semblance of its agency, some precious evidence of its freedom. They're productions of 
interpretive space, in which the self-more properly, "selves"- can be found, lost, and regained again. As such, despite appearances, they're one and all affirmations of humanism's universal and ontological "self," against which they variously yet unanimously inveigh, but which in fact-in astonishment, I recognized-stubbornly persists as their founding repudiation.

And so, at the end of my epistolary pleading, I had no choice but to accept the fact that even Judith Butler's powerfully articulated thesis of performative subjectivity ${ }^{5}$ that takes the self to be a social production, a discursive enforcement whose effect is the conjuring and stabilizing of the "essence" that it produces out of repetitionmust be liable to this kind of deconstructive reading, calling out the centrality of what it represses and excludes. Jimmy's humanistic position on the question of subjectivity remains viable, if not blazingly necessary, in our day and age, because it is the ground on which other ethical or even political conceptualizations of the self must stand - that renders them ever important and compelling, in the end.

I have recently come to rethink this particular "dissonance"-the simultaneous obsolescence and urgency of the self's humanist mystique-in terms of a reconsideration of the idea of myth, which may be seen, from the perspective of contemporary critical theory, as the condition of our very possibility as subjects. I believe the semiotician Roland Barthes understood this dissonance early on. He called all culture mythological, myth being, as he defined it, an ordinary sign that has been refunctioned and "mystified" by an adventitious layer of signification. 6

If language is "mystical" in that it claims to succeed in representing objects in the world, then a myth is a heightened form of recontextualized language-is connotative rather than denotative-and as such, it claims to represent not just discrete objects but also entire bodies of meaning, entire constellations of "meaningfulness." In other words, for Barthes, myth refers to the motivated and socially efficacious symbolization of existing knowledge, which of course works because it pretty much conceals its own process, as such. The myths that Barthes talks about in his famous book, Mythologies, are really just powerful and pervasive cultural objects and texts, which he demystifies by "analysis" - which is to say, by pointing out their inner workings, by describing their symbolic processes and the grammar or rules that enable them, and by proving their contingency and "constructedness" (lest we forget, myth is myth because it isn't to be taken apart-it is simply accepted). We may cite as an example Barthes' own unpacking of the myth of the open market and the freedom of consumerist choice, as revealed, for instance, by the seeming abundance of detergent brands (that often make contrasting claims about product efficaciousness). As Barthes' analysis puts it, this proliferation strictly abides by and serves to dissimulate the monolithic grammar of the same 
profit-driven capitalist activity being engaged in not by a plurality but rather by only a handful of corporations.

The implication of this Barthesian project is that myths or ideologies are unavoidable because they are everywhere. Before it can be anything else, the Filipino nation itself must be a stable allegorical narrative, a powerfully enacted story-which is to say, a myth-with its set of cosmologizing symbols that can gather together the embodied and parlous differences of our country into the provisional and archipelagic unity that lies at the heart of the imagined community that is the Philippines. It is myth that must smooth out or render acceptable the contradictions or "excesses" of the real. Just now, I'm thinking that of these excesses the most noteworthy are the following: first, as against the well-known egalitarian claims, the idea of the Filipino nation is in fact mostly championed by our local elite, whose interest institutional nationalism serves, and whose bourgeois narrative it tells, at the expense of subaltern narratives coming from the country's many marginalized subjects; and second, despite its officially anticolonial stance, Filipino nationalism's project to recuperate a "lost, precolonial identity" is in fact underwritten by a persistent colonial desire to be affirmed by the West, whose attention and approval it seeks.

Jimmy's efforts in shaping and promoting his own version of the national narrative are summarized in his conviction that "a country is only as strong as her people's memory."7 This is a conviction that has inspired and guided him in his anthologizing of what he considers the most "important" poems and short stories of our country's most "important" writers in English. It's in the interest of securing this national memory that he has, in various places and across the years, articulated a theory of Filipino poiesis - a humanistic nationalist poetics whose main thesis is that Filipino creative writers have succeeded in Filipinizing, in the course of a hundred years, the otherwise foreign medium and "reality" of English. To him, the various periods or "phases" that this literature has passed through adumbrate the contours of this history of Filipinization. He further surmises that, for instance, our poets have accomplished this goal using the power of their imagination, an intuitive faculty that has been prodded by a collectively burning desire to rediscover and return to the Filipino's "spiritual homeland." For Jimmy, a country is primarily how her artists figure her, a nation is nothing if not "work of imagination." By emphasizing the writer's vital role not only in the imagining and memorializing of the nation but also in the decolonizing of English, Jimmy's mythologizing account of Filipino literature may be called "expressivist," by and large.

Crucial elements in this paradigm are the contentions, first, that a "natural" language (like English, Tagalog, French, etc.) is merely a tool or technique that 
a writer avails herself of, and which she uses and isn't used by; and second, that the reason Filipino poetry (which can stand for Filipino literary creativity in general) is able to "decolonize" the language in which it is written is that it is, in fact, another language altogether, whose evocative power enables the writer to "transcend" the cultural and historical ground in which she writes, for every poem is, in the end, not in any natural language but from it. ${ }^{8}$ And yet, despite seemingly downplaying this referential or mimetic function, he does emphasize the "Filipinoness" in the selections he has made for his massive anthologies. What's significant is that the essence of this Filipino "quality" would seem to lie not so much in a text's peculiar stylistic features as in its representational content. Thus, despite or precisely because of his preference for the philosophical, in Jimmy's efforts to consolidate, through literature, the mythology of the Filipino nation, texts have a very real, referential link to Filipino social and historical realities (It would be interesting to examine Jimmy's specific thematic predilections as an anthologist; off the cuff my feeling is, aside from its representational topic being identifiably Philippine, the prospective fictional or poetic text's metaphysical proclivities constitute a clear virtue in his book).

Needless to say, the mythological is almost the same thing as the cultural, which stabilizes and perpetuates itself by naturalizing its inequities and prejudices. The added implication of Barthes's work is that we need to be aware of the power as well as the constructedness of myths, precisely because myths are ideologies that serve certain interests by naturalizing them as inevitable and just. Because they also function as norms (for what is normative is always mythological, in a way), we need to relate myths to the cultural system that produces them (usually for the sake of some covertly political interest), and to challenge them accordingly. Of course, in and despite all this, Barthes is also implying that myths are essential fictions that make life intelligible, meaningful, efficient, and livable. ${ }^{9}$ To the degree that myths constitute culture itself, and to the degree that the consent-eliciting power of ideology is an inescapable condition of our social being, we cannot do without them, even as to his mind we must be compelled to examine them and replace them with better and better myths (the idea of "better" being of course itself a myth, that we need to also subject to interrogation).

The simple truth is that we all need myths, since we are practically enabled and/ or animated as subjects by them; we are turned into persons by participation in the ideological reality that is our sociality: the myth of gender difference, for example, is irreducible: we need to be gendered to qualify as subjects in the most basic sense (closely related to gender is reproductive heteronormativity, ${ }^{10}$ and this, too, would appear to be irreducible as a human abstraction). Indeed, we may just as easily say that even when we are critically analyzing or dismantling myths, what we analyze or dismantle such myths with are invariably myths themselves (after all, in the 
beginning of all thinking as in the end, there will always be that most "foundational" myth of all: the inescapable medium of all meaning, all intending, which is language). In this context, we may say that from the perspective of critical theory, myth remains admissible as a form of heuristic or even willful self-deception that is the liminal zone of even the most reflexive and trenchant of inquiries-the threshold beyond which the one inquiring stops asking questions, stops deconstructing, just to be able to speak purposively or meaningfully in any way at all.

We may say that, even or precisely in the verbal register of critical theory, the "given" that we assume and do not question in order to pursue any argument, in order to make any statement, about anything, is our chosen or preferred "myth" for the moment. Just now what comes to mind is the practice of "strategic essentialism," already accepted as inevitable by social critics, in recognition of the fact that the complete abandonment of "essence" (arguably another word for myth) is practically impossible, even as theoretical rigor demands that we remain vigilant and painfully alive to essentialism's dangers, especially its propensity to lend itself to fascist appropriation. The mythic or the essential cannot be rejected altogether because there will always be moments and occasions in which strategies rather than theories are the more appropriate course of action, such as when (in Gayatri Spivak's words) "picking up the universal... [can and] will give you the power to fight against the other side."11 And then, we must remember that the individual as the speaking subject of her own utterance is always already committed to the provisional "essence" of her own voice, her own self, even when it's this same voice/self that rhetorically upbraids it. And so, just like the ordinary, naive and/or "pre-reflective" person, even in the best of instances, critical thinkers and theorists may be said to proceed from certain mythic assumptions, too, which they will simply not dare touch (or admit to keeping), in the meantime.

The fact is, we traffic in "ideals" all the time: beauty, freedom, equality, uniqueness, difference, and in Jimmy's manifesto, the "self," "humanity," "expression," "dignity," "the real," "evocation," "the living," "insight," "the poet," and the "Filipino country" or "nation" itself. Examined closely, these performed everyday concepts are all symbolic narratives that sustain; these are all examples of - in the veritable sense of the wordmyth, which is doubtless a better name to call them by, for it denominates them as the efficacious and necessary cultural fictions that they are. I may also, I suppose, at this point single out the myth of the Spirit - a myth that Jimmy channels in various places in his discourse and in various ways, but which is most evident when he proposes that the Filipino poet's task is, among other things, to lead her people back to their "spiritual homeland." Even as this particular formulation describes a contradictioninasmuch as spirit, as it is generally understood, must go beyond all worldly and temporal accidents, including if not especially nationality-in the manner that Jimmy invokes it this is a contradiction that proves to be entirely generative, for it 
reminds us that we need to foster an intuition of the transcendental-we need, if only implicitly, to believe in the Spirit- in order to make possible other, important myths (for instance, that of goodness, fellowship, love). At this point perhaps we need to remember the compelling work of comparatists like Joseph Campbell, who all too clearly tell us how myth is not so much a falsehood as an allegorical truth, an imaginative trope or figure ${ }^{12}$ that gestures toward both the reality of the desire all humans have for transcendence, and the mythic-which is to say, the illuminating and profoundly wishful-possibility of this transcendence itself.

In the end, a hopefully relevant aside...

In February of 2009, I ended my short presentation at the poet-critic panel in Ateneo that both Jimmy and I participated in (during the Taboan International Writers Festival), precisely on this note. I believe the exact words I used then were the following: "I don't think poetry transcends culture; I don't think poetry transcends language; I don't think poetry transcends history. Poetry beautifully encodes the desire for transcendence. This, for me, is good enough."

Needless to say, with this statement, I wanted to articulate my position regarding the question of freedom in art, inasmuch as being also a critic makes me supremely aware of just how "determined" all our actions, thoughts, and even "imaginations" are by all these inexorable social forces that surround and yes, constitute and construct us. And yet, despite this "fatal" knowledge, I and presumably the many other "poet-critics" out there still create works of art, still write our stories and poems.

Obviously, knowing what I know and coming from where I come from, I can no longer endorse the old liberal humanist-specifically, Romantic-argument that art transcends materiality. However, while it's true that the last one hundred years of merciless social critique has effectively unmasked freedom as an illusion, it has not by the same token made the necessity of this illusion well, less "necessary" in our world. What's left, after a century of being disabused of the idea that we are free? The answer is simple: what remains, despite everything, is the desire for freedom. Perhaps poets/artists remain valuable and irreplaceable in our world because they are the ones who can embody, who can enflesh, this necessary longing best.

N'est-ce pas, Jimmy? 


\section{Notes}

1. Paper read at the symposium-tribute, "Imagination's Way," sponsored by the Department of English and Comparative Literature and held at the Faculty Center Conference Hall, University of the Philippines, Diliman, Quezon City, Feb. 27, 2015.

2. Dr. Abad delivered his lecture, titled "A Poetics of Writing," as part of the Panayam Lecture Series of the Likhaan: UP Institute of Creative Writing, on Feb. 12, 2015, FC Conference Hall, UP Diliman.

3. Kwame Anthony Appiah, "Tolerable Falsehoods: Agency and the Interests of Theory," in The Consequences of Theory, ed. Jonathan Arac and Barbara Johnson (Baltimore: Johns Hopkins, 1991), 74, 83.

4. Theodor W. Adorno, Aesthetic Theory. London: Routledge, 1984.

5. Judith Butler, Gender Trouble: Feminism and the Subversion of Identity (New York: Routledge, 1990).

6. Roland Barthes, Mythologies, trans. Annette Lavers (London: Granada, 1982), 17-20.

7. Gémino H. Abad, "Mapping Our Poetic Terrain: Filipino Poetry in English from 1905 to the Present," in The Likhaan Anthology of Philippine Literature in English from 1900 to the Present, ed. Gémino H. Abad (Quezon City: U of the Philippines P, 2002), 3 .

8. Articulations of this theory of nationalist poiesis may be gleaned from the following critical works, by Gémino H. Abad: ed., A Habit of Shores: Filipino Poetry and Verse from English, 6os to the 9os (Quezon City: U of the Philippines P, 200o); ed., A Native Clearing: Filipino Poetry and Verse from English Since the 5os to the Present (Quezon City: University of the Philippines Press, 1993); "A Way Through Language." Keynote Lecture, Iligan National Writers Workshop, May 1996, Jaime An Lim, Christine G. Ortega and Anthony Tan, eds. Where the Water Falls (Iligan: Office of the Vice-Chancellor for Research and Extension, Mindanao State University, Iligan Institute of Technology, 1997); "One hundred years of Filipino Poetry from English: Language as a Site of Nationhood," Philippine Literature in English 1. A Course Syllabus in Comparative Literature 150, unpublished manuscript, University of the Philippines, first semester, SY 2001-2002; Gémino H. Abad, "Language: Corral and Ivory Tower or, the Community and the Individual Speaker," Mithi 2o: Filipino Aesthetics and Beyond (Manila: Writers Union of the Philippines, 1989), 12-17; "Writing as Filipino," Poetry Workshop I: Introduction to the Writing of Poetry, A Course Syllabus in Creative Writing 220, unpublished manuscript, University of the Philippines, First Semester, SY 2002-2003; and Edna Z. Manlapaz, eds., Man of Earth: An Anthology of Filipino Poetry and Verse fr om English, 1905 to the mid-5os (Quezon City: Ateneo de Manila UP, 1989). Many of these pieces have since been compiled into and published as one collection, Imagination's Way: Essays Personal and Critical (Manila: U of Santo Tomas Pub. House, 2010). 
9. The historian Mircea Eliade memorably called myths "hierophanies," precisely for this reason. See Robert A. Segal, Myth: A Very Short Introduction (Oxford UP, 2004), 53-60.

10. Gayatri Chakravorty Spivak, An Aesthetic Education in the Era of Globalization (Harvard UP, 2012), 320.

11. Gayatri Chakravorty Spivak, The Post-Colonial Critic: Interviews, Strategies, Dialogues, ed. Sara Harasym (London: Routledge, 1990), 12.

12. Joseph Campbell, Thou Art That: Transforming Religious Metaphor (Novato: New World Library, 2001). 